\title{
Antibodies to the five histones and poly(adenosine diphosphate-ribose) in drug induced lupus: implications for pathogenesis
}

\author{
RODERICK N HOBBS, ${ }^{1}$ ANNE-LOUISE CLAYTON ${ }^{2}$ AND \\ ROBERT M BERNSTEIN ${ }^{3}$
}

From the ${ }^{1}$ Robert Jones and Agnes Hunt Orthopaedic Hospital, Oswestry, Shropshire; the ${ }^{2}$ WellconRe Research Laboratories, Beckenham, Kent; and the ${ }^{3}$ Rheumatism Research Centre, University of Mancheste̋s, Manchester

SUMMARY Certain drugs are a frequent source of antinuclear antibody (ANA) induction, ang ANA is invariably present in the few patients who progress to the drug induced lupus syndrome. This report concerns the fine specificity of the ANA response to hydralazine, penicillamine, and sulphasalazine therapy. Using highly purified individual histones in fluorimetric assay@ antihistone antibodies are always detectable, often in large amounts, but the pattern of response to individual histones is variable and not drug specific. In addition to the response to the three histones $\mathrm{H} 1, \mathrm{H} 2 \mathrm{~B}$, and $\mathrm{H} 3$ reminiscent of idiopathic systemic lupus erythematosus, antibody to histone $\mathrm{H} 2 \mathrm{~A}$ predominates in some drug induced cases. Contrary to previous thought, histone are not the sole target of the antinuclear response: we also demonstrate a significant correlation between ANA titre and antibody to poly(adenosine diphosphate-ribose). Like the histones, this is a macromolecule that can bind to deoxyribonucleic acid (DNA). It is proposed that drug induced damage to chromatin leads to ANA production, while drug induced impairment $\frac{8}{8}$ complement activity may then enable these autoantibodies to mediate the lupus syndrom $\mathcal{S}^{\circ}$

Key words: antinuclear antibody, adverse drug reaction, hydralazine, D-penicillamine, sulph. salazine, prizidilol.

Antinuclear antibodies (ANA) often develop during long term therapy with a number of drugs, though the drug induced lupus syndrome is less common. ${ }^{-4}$ Such ANA are associated with the LE cell phenomenon and generally give the homogeneous pattern of nuclear immunofluorescence ${ }^{5-9}$ characteristic of chromatin antigens such as DNA and histones. With few exceptions (captopril and penicillamine), very little antibody is induced to native DNA, and recently attention has turned to the histones. By an immunofluorescence technique on acid extracted tissue reconstituted with histones, antihistone antibodies were said to be the sole ANA specificity in patients with the lupus syndrome induced by procainamide or isoniazid, ${ }^{5}$ yet in the

Accepted for publication 5 November 1986.

Correspondence to Dr Robert M Bernstein, Rheumatism Research Centre, The Royal Infirmary, University of Manchester, Oxford Road. Manchester M13 9WL. case of hydralazine such antibodies were no detected,${ }^{69}$ or were restricted to patients with actipe drug induced lupus syndrome. ${ }^{8}$ By radioimmunoassay, ${ }^{7}$ antihistone antibodies were foumd to be induced by hydralazine as well as prcainamide, but only the larger amounts induced \#y procainamide were detectable on tissues reconsop tuted with histones. It was suggested that these drugs also differ in the type of histone to which antibodies are induced, but it has remained an opep question whether other nuclear antigens are i⿺辶volved.

The five histones are small, highly conserved, DNA binding proteins, rich in basic amino acids but lacking sequence homology. ${ }^{10}$ In idiopathic system lupus erythematosus (SLE), antihistone antibodio 5 are common, albeit often in modest amounts, and they react mainly with histones $\mathrm{H} 1, \mathrm{H} 2 \mathrm{~B}$, a d H3. ${ }^{11-13}$ In rheumatoid arthritis with vasculitis t5e response is chiefly to histones $\mathrm{H} 2 \mathrm{~A}, \mathrm{H} 2 \mathrm{~B}$, and 


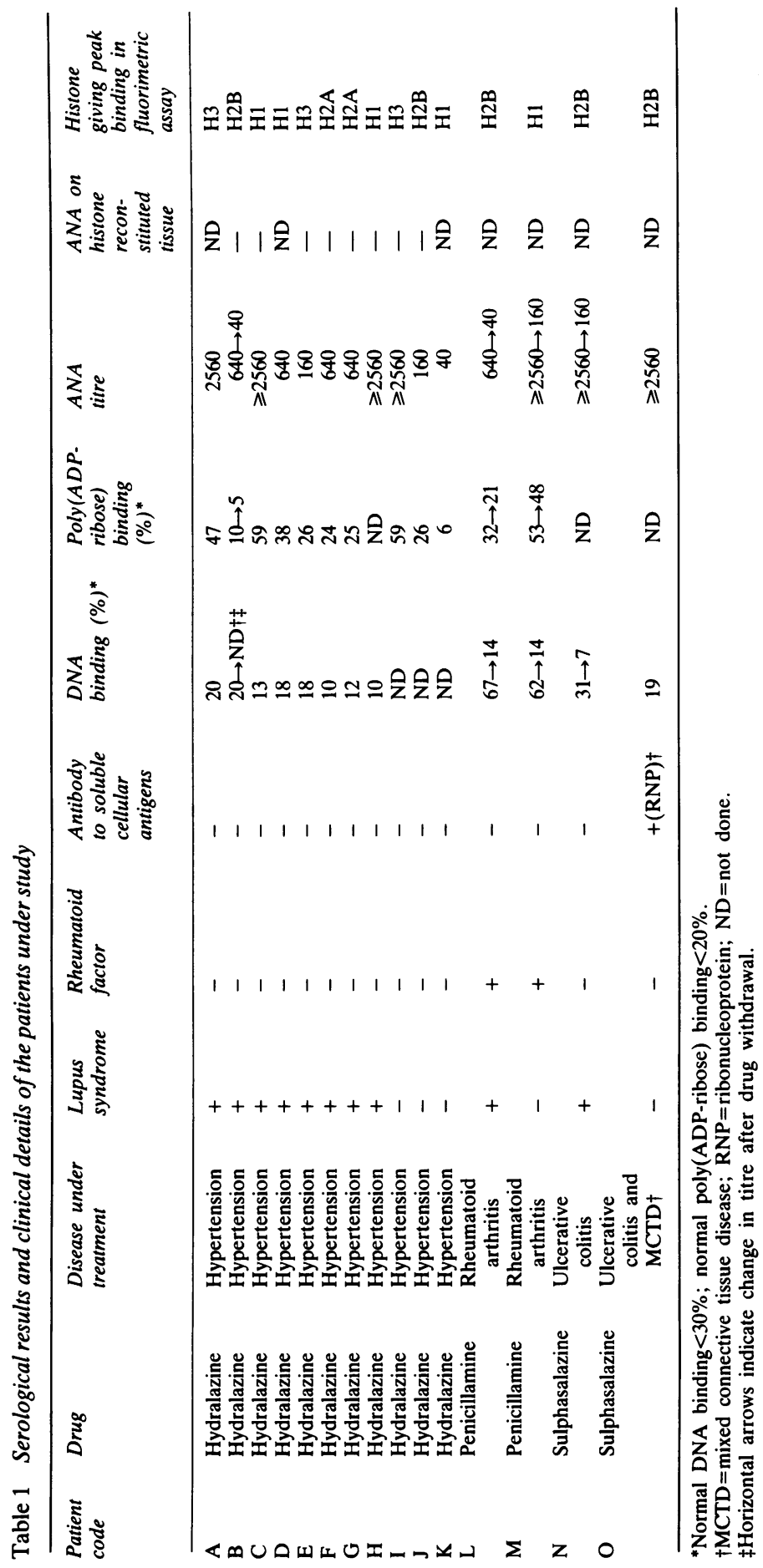


H4. ${ }^{1314}$ For the present study we have used the same highly purified histones and the same solid phase fluorimetric assay as in our previous studies $^{13-15}$ to describe the fine specificity and variety of antihistone antibodies induced by three drugs in common use-hydralazine, sulphasalazine, and D-penicillamine. ${ }^{1} 1617$ We go on to show that the drug induced antinuclear response involves not only histones but at least one other chromatin associated antigen, poly(adenosine diphosphate-ribose).

\section{Patients and methods}

As shown together with the serological and diagnostic data in Table 1 , serum was obtained from 10 patients with drug induced lupus and four patients with a high or rising titre of ANA during drug therapy. In addition, a patient with mixed connective tissue disease and ulcerative colitis was studied while under treatment with sulphasalazine. Eight healthy controls were included in the histone binding assays. A further 25 sera were included in the Farr assay for antibody to poly(adenosine diphosphate-ribose); these were serial samples from nine patients who developed ANA during treatment with the antihypertensive drug prizidilol. ${ }^{18}$

The drug induced lupus syndrome was diagnosed on clinical grounds ${ }^{13}$ and confirmed by its resolution after withdrawal of the drug. The most frequent features were arthralgias or arthritis, myalgias, malaise, weight loss, anaemia, and raised erythrocyte sedimentation rate. ${ }^{3}$ In addition patient $\mathrm{A}$ had cutaneous vasculitis, ${ }^{19}$ patient $\mathrm{L}$ developed increased DNA binding by the Farr assay, ${ }^{20}$ and patient $\mathrm{N}$ had a pleural effusion. All these clinical features resolved within a few weeks of discontinuing therapy with the offending drug.

\section{FLU ORIMETRIC ASSAY}

The fluorimetric assay was performed as described in detail elsewhere, ${ }^{14}$ using histones purified and generously provided by Dr E W Johns. ${ }^{21}$ Polystyrene EIA cuvettes (Gilford) coated with tyrosineglutamic acid (1:1) copolymer of mol.wt 66000 (Miles-Yeda) followed by histone were incubated with $5 \%$ serum in $0 \cdot 1 \%$ Tween borate-saline buffer $\mathrm{pH} 8.2$ and then fluorescein isothiocyanate (FITC) labelled sheep antihuman immunoglobulin, IgG or IgM (Wellcome). For the IgG subclass assays, FITC labelled sheep antiserum was replaced by unlabelled sheep antihuman IgG subclass specific antiserum (Miles) (1 vol antiserum: $5 \mathrm{vol} \mathrm{normal} \mathrm{rabbit} \mathrm{serum:}$ 24 vol borate-saline-Tween 20 buffer) followed by an additional overnight incubation with FITC labelled rabbit antisheep IgG (Miles) (1 vol conjugate: 5 vol normal rabbit serum: 114 vol Tween buffer). The conjugate was released by $1 \mathrm{ml} 0 \cdot 1$ $\mathrm{NaOH}$ containing $0 \cdot 1 \%$ sodium dodecyl sulphate. Fluorescence was measured on a fluorimeter (Locarte, London) and expressed in arbitrary unito.

A N A DETERMINATION

Sera were tested in fourfold dilutions, $1 / 10-1 / 256 \overline{\mathrm{A}}$, on rat liver frozen sections using FITC labellêd sheep antihuman whole immunoglobulin (WelPcome, Dartford). ${ }^{3}$

HISTONE RECONSTITUTION ASSAY Using the method of Tan et al, ${ }^{5} 22$ serum dilutiobs $(1 / 10-1 / 2560)$ in phosphate buffered saline (PBË) were tested by indirect immunofluorescence की acetone fixed, mouse kidney frozen sections which were $(a)$ extracted with $\mathrm{HCl}(0 \cdot 1 \mathrm{M})$ for $30 \mathrm{~min}$ th room temperature, washed, and incubated with PBS $(30 \mathrm{~min})$; or $(b)$ extracted with $0 \cdot 1 \mathrm{M} \mathrm{HCl}$, washed, and reconstituted by incubation with total histones or histone fractions (Millipore) at $25 \mu \mathrm{g} / \mathrm{ml}$ in P矢 (30 $\mathrm{min})$; or $(c)$ incubated in PBS throughout.

FITC labelled sheep antihuman immunoglobulim (Wellcome) was employed, and a positive control antihistone serum was kindly provided by Dr E Tan.

POLY(ADENOSINE DIPHOSPHATE-RIBOSE) B IN D ING ASSAY

Antibody to ${ }^{3} \mathrm{H}$ labelled poly(adenosine diphoß phate-ribose), synthesised in vitro from $\left[{ }^{3} \mathrm{H}\right]$ nic $\overrightarrow{\overrightarrow{0}}-$ tinamide adenine dinucleotide and kindly provided by $\operatorname{Dr} M$ Tavassoli and Professor S Shall, w\$ measured by the Farr assay as described in detail previously. ${ }^{23}$ Sera from 20 healthy controls and $2 \$ 5$ patients with various idiopathic autoimmune diseases were studied at the same time. ${ }^{23}$

OTHER AUTOANTIBODIES

Antibody to ${ }^{3} \mathrm{H}$ labelled native DNA (Amersham, UK) was measured by the Farr assay ${ }^{24}$; antibodios to soluble cellular antigens were sought usipgr counterimmunoelectrophoresis ${ }^{25}$; rheumatoid factor was detected by the slide latex test (Ortho Diang nostics, UK).

\section{Results}

ANTIHISTONE ANTIBODIES BY

FLUORIMETRIC ASSAY

\section{Controls}

Using the five purified histones, normal ranges were established for the whole immunoglobulin (Ig), Ig $\bar{G}$, and IgM specific assays (Table 2). In the Ig subclass specific assays three control sera gape binding values of $0.02-0.05$ with $\operatorname{IgG}_{1}, \operatorname{IgG}_{2}$, aged $\mathrm{IgG}_{4}$, and of $0.03-0.07$ with $\mathrm{IgG}_{3}$. 
Table 2 Histone binding values (fluorimeter units) using sera from healthy controls in assays specific for total immunoglobulin (Ig) and the IgG and IgM classes

\begin{tabular}{llllll}
\hline & $H 1$ & $H 2 A$ & $H 2 B$ & $H 3$ & $H 4$ \\
\hline Ig $(\mathrm{n}=8)$ & & & & & \\
mean & 0.098 & 0.086 & 0.068 & 0.096 & 0.092 \\
mean+2SD & 0.12 & 0.11 & 0.90 & 0.12 & 0.10 \\
$\quad \begin{array}{lllll}\text { IgG }(\mathrm{n}=5) \\
\quad \text { mean }\end{array}$ & 0.030 & 0.026 & 0.025 & 0.034 & 0.035 \\
$\quad$ mean+2SD & 0.043 & 0.034 & 0.029 & 0.039 & 0.043 \\
IgM (n=5) & & & & & \\
$\quad$ mean & 0.047 & 0.040 & 0.040 & 0.067 & 0.051 \\
mean+2SD & 0.058 & 0.049 & 0.054 & 0.117 & 0.062 \\
\hline
\end{tabular}

$\mathrm{SD}=$ standard deviation; mean $+2 \mathrm{SD}$ was set as the upper limit of normal.

\section{Hydralazine}

Histone binding was raised in all 11 cases of hydralazine induced ANA (Figs 1 and 2), whether the patient had the lupus syndrome $(\mathrm{A}-\mathrm{H})$ or not (I-K). Antibodies to all five histones were above normal in each case, but often reactivity with one or two histones was predominant. Peak binding involved $\mathrm{H} 1, \mathrm{H} 2 \mathrm{~A}, \mathrm{H} 2 \mathrm{~B}$, and $\mathrm{H} 3$ in different cases;
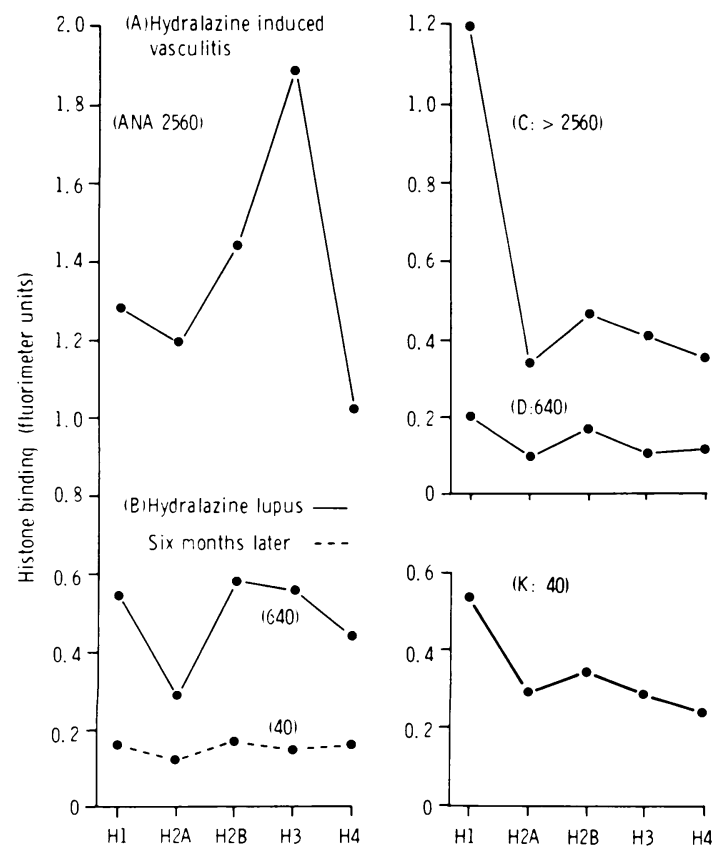

Fig. 1 Patterns of immunoglobulin binding to the five individual histones obtained with sera from four patients with the hydralazine induced lupus syndrome $(A-D)$ and one with hydralazine induced $A N A(K)$. The ANA titres are shown in parentheses.

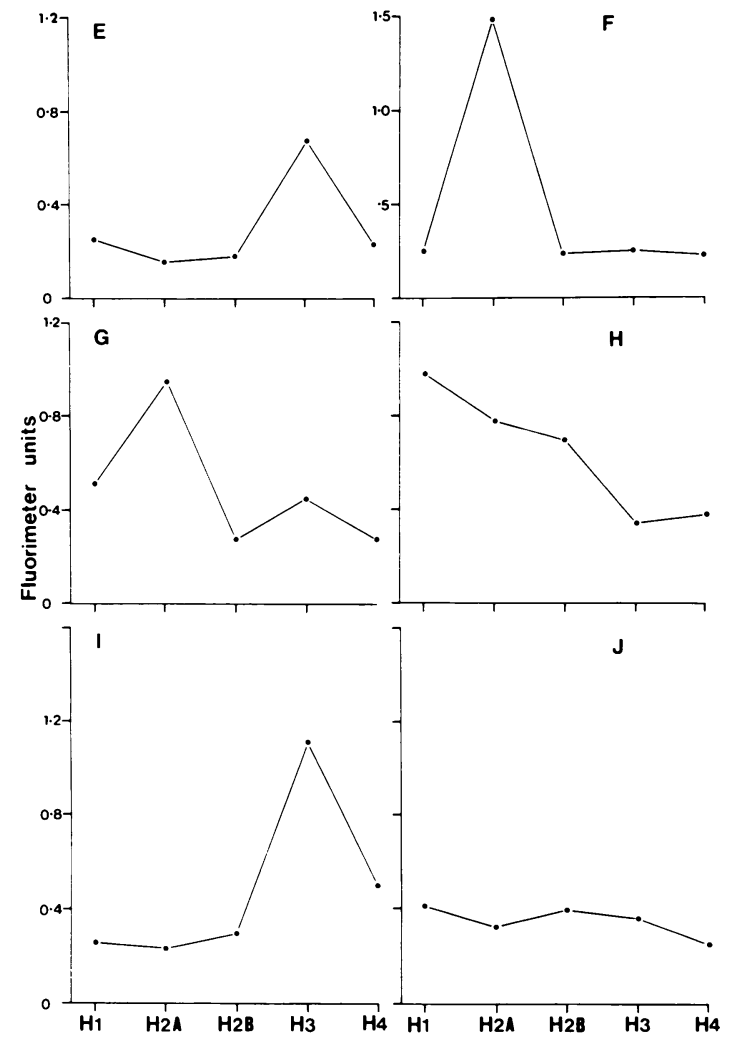

Fig. 2 Patterns of immunoglobulin binding to the five histones obtained with serum from four patients who had hydralazine-lupus $(E-H)$ and two patients with just hydralazine induced ANA $(I, J)$.

there was no consistent pattern. The highest binding values were obtained with serum from patient $\mathrm{A}$ who had drug induced cutaneous vasculitis. ${ }^{19} \mathrm{~Pa}-$ tient $\mathrm{B}$ was followed up longitudinally and showed parallel falls in ANA titre and histone binding over the six month period after discontinuing hydralazine therapy. Six sera were tested for $\mathrm{IgG}$ and IgM class specific histone binding (Fig. 3); the response was chiefly IgM antibody in three cases $(E$, $\mathrm{I}, \mathrm{J}), \mathrm{IgG}$ in one case (F), and mixed in two cases $(G, H)$. The IgG subclass reactivity (Fig. 4) mirrored the pattern of whole IgG binding to a varying extent. Histone binding was generally higher than in idiopathic SLE, ${ }^{13}$ but some sera (D, J, K) gave modest binding despite high ANA titres. ${ }^{26}$

\section{D-Penicillamine}

Two patients (L, M) under treatment with Dpenicillamine for rheumatoid arthritis were selected 


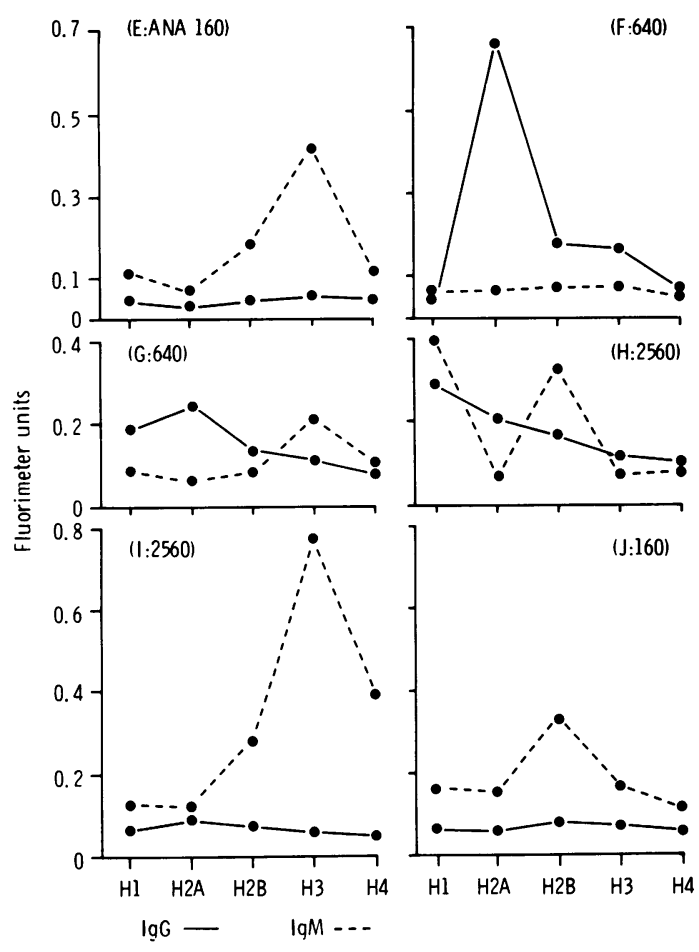

Fig. 3 Patterns of IgG and IgM binding to the histones using the same sera as in Fig. 2. ANA titres are shown in parentheses.

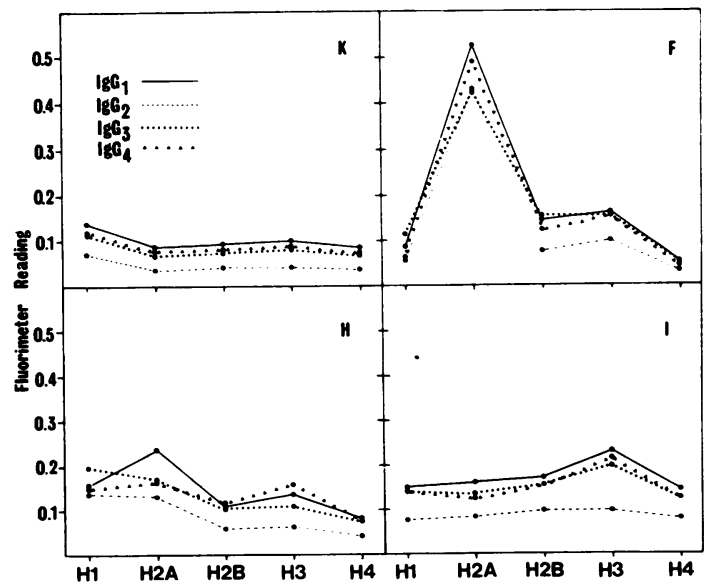

Fig. 4 Patterns of IgG subclass specific histone binding using sera from two patients with hydralazine-lupus $(F, H)$ and two with ANA without lupus $(I, K)$. because high DNA binding activity had appeares. during therapy; in one case (L) there was a cleat cut clinical deterioration with malaise, fever, an worsening arthritis that resolved on drug with drawal. Both sera gave raised histone bindin (Fig. 5), but the patterns differed, showing simila rises to all histones in one case (L) and a peak of anti-H1 activity in the other (M). In both case ANA titre, histone binding, and DNA binding feff in the months after drug withdrawal.

\section{Sulphasalazine}

Serum from two ANA positive patients receivim sulphasalazine therapy for ulcerative colitis showed raised histone binding. In both cases this was predominantly to $\mathrm{H} 2 \mathrm{~B}$ (Fig. 5). One patient $(\mathrm{N})$ had drug induced lupus, whereas in the other $(\mathrm{O})$ the rheumatic disease (mixed connective tissue diseasê was idiopathic and preceded sulphasalazine therapy.

\section{ANTIHISTONE ANTIBODY ON TISSUE}

SECTIONS RECONSTITUTED WITH HISTONES

We compared our fluorimetric assay with the old immunofluorescence ANA technique for antihis tone antibodies. ${ }^{22}$ Serum samples from six patientfs with hydralazine induced lupus and from the patients with ANA but without lupus were tested fo्fr antihistone antibodies by immunofluorescence of tissue sections that had been extracted with acid argd reconstituted with total histones or the $\mathrm{H} 2 \mathrm{~A} / \mathrm{H} 2 \mathrm{~B}$ fraction. In no case was antihistone antibody d\&tected in this way (Table 1), though the positive control serum reacted strongly. We conclude that the antigens recognised by hydralazine inducedd ANA are not generally reconstituted by this technique. Various explanations will be discussed but these data raise the possibility that some nomhistone antigen is involved.

ANTIBODY TO POLY(ADENOSINE DIPHOSPHATE-RIBOSE) INDUCEDBYDRUGS We reported previously that antibodies to the cellular macromolecule poly(adenosine diph $\overline{\overline{Q S}}$ phate-ribose) can be induced by three drugs that induce ANA. ${ }^{23}$ The relation between ANA titye and the Farr assay result for poly(adenosine diph@ phate-ribose) binding is shown in Fig. 6. The data include those from Table 1 (concerning hydralaziूe and penicillamine) and additional serial measufements made in nine patients who developed ANA during treatment with prizidilol, an antihypejtensive agent structurally related to hydralazineos Six $(75 \%)$ of eight patients with drug induced lupis and nine $(64 \%)$ of 14 further patients with drâtg induced ANA at a titre of at least $1 / 160$ gaye poly(ADP-ribose) binding above $20 \%$. By way of 

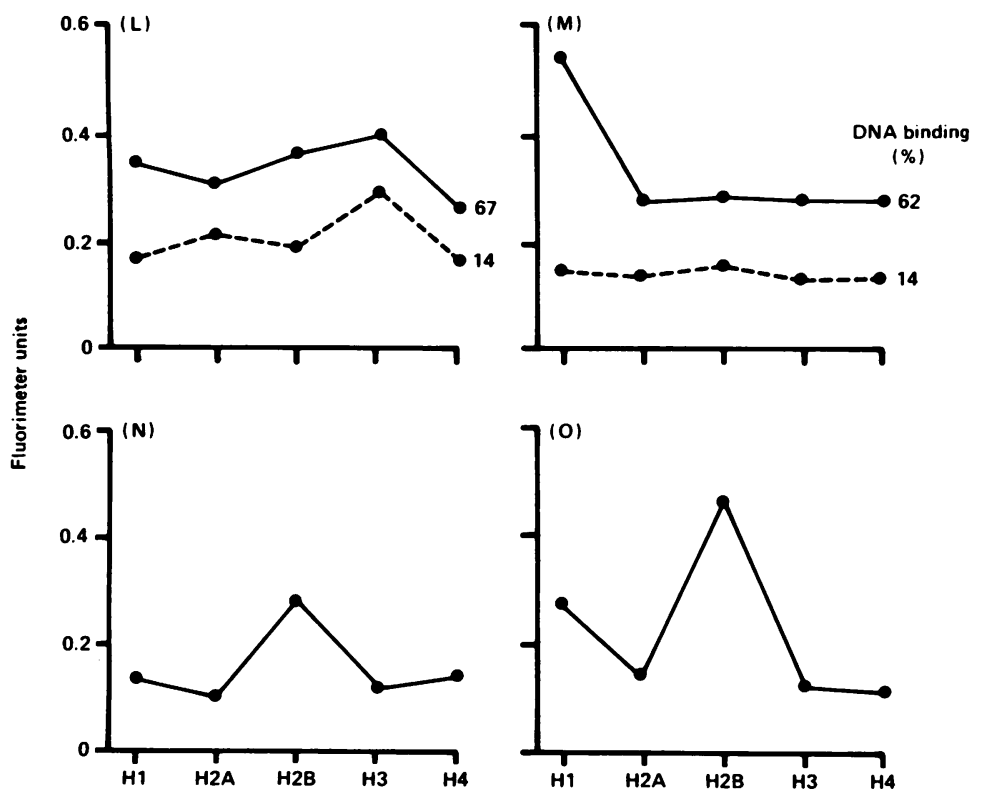

Fig. 5 Upper panels: histone binding and DNA binding induced by D-penicillamine $(L, M)$ just before (-) and about six months after (- - ) cessation of therapy with this drug. Lower panels: histone binding patterns in a patient with

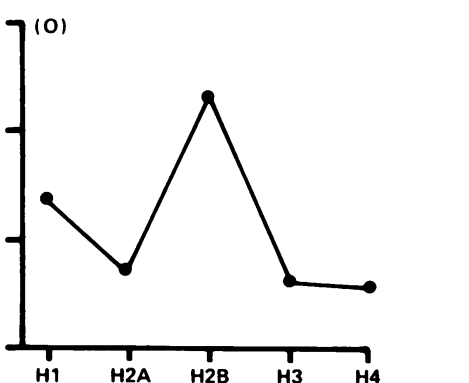
sulphasalazine induced lupus $(N)$ and a patient with pre-existing mixed connective tissue disease and ulcerative colitis who was treated with sulphasalazine $(O)$.

(Reproduced by permission of the University Department of Medical Illustration, Royal Infirmary, Manchester M13 9WL, UK.)

comparison only $54 \%$ of 61 SLE sera and $3 \%$ of 144 other rheumatic and autoimmune disease controls gave binding values of $20 \%$ or more; the highest binding value shown in SLE was $64 \%$. ${ }^{23}$ The correlation evident in Fig. 6 between ANA titre and the Farr assay result for poly(adenosine diphosphateribose) binding is confirmed by regression analysis $(\mathrm{p}<0.01)$.

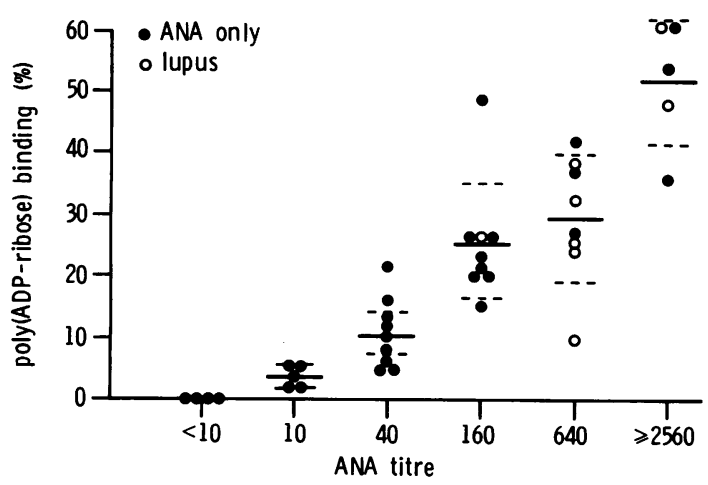

Fig. 6 Relation between poly(adenosine diphosphate-ribose) binding measured by the Farr assay and ANA titre measured on rat liver substrate $(O=d r u g$ induced lupus; $=$ drug induced $A N A$ without lupus). The data include 15 measurements on 12 patients shown in Table 1 and a further 25 serial measurements in nine hypertensive patients who developed ANA while being treated with prizidilol. ${ }^{18} 23$

\section{Discussion}

Our results show that high levels of antihistone antibody can be induced by therapy with hydralazine, penicillamine, and sulphasalazine, but that the pattern of response to individual histones is variable. Antihistone antibody is not the sole antinuclear specificity involved, since antibody to another chromatin associated antigen, poly(adenosine diphosphate-ribose), is present in amounts that correlate with the ANA titre.

Antihistone antibodies occur in a variety of conditions ${ }^{13} 1422$ and are not therefore specific for drug induced lupus. The antihistone response in drug induced lupus is generally greater than in idiopathic SLE, and the pattern is more variable, with histones $\mathrm{H} 1, \mathrm{H} 2 \mathrm{~A}, \mathrm{H} 2 \mathrm{~B}$, and $\mathrm{H} 3$ predominant in different cases. As in SLE, there was relatively little antibody to histone $\mathrm{H} 4$, but in contrast with SLE (where the response to $\mathrm{H} 2 \mathrm{~A}$ is usually small and never predominant ${ }^{13}$ ), $\mathrm{H} 2 \mathrm{~A}$ gave peak binding in two of the eight cases of hydralazine-lupus. The various patterns of antihistone response exclude a systematic bias in the sensitivity of the assays for antibody to each histone. This is emphasised by disease related differences in the pattern of response $^{13}$ : in SLE the response to $\mathrm{H} 1$ greatly exceeds that to $\mathrm{H} 4$, whereas the reverse is true in rheumatoid vasculitis (Fig. 7). The various patterns of drug induced histone binding showed no correlation with the titre of ANA, the presence or 

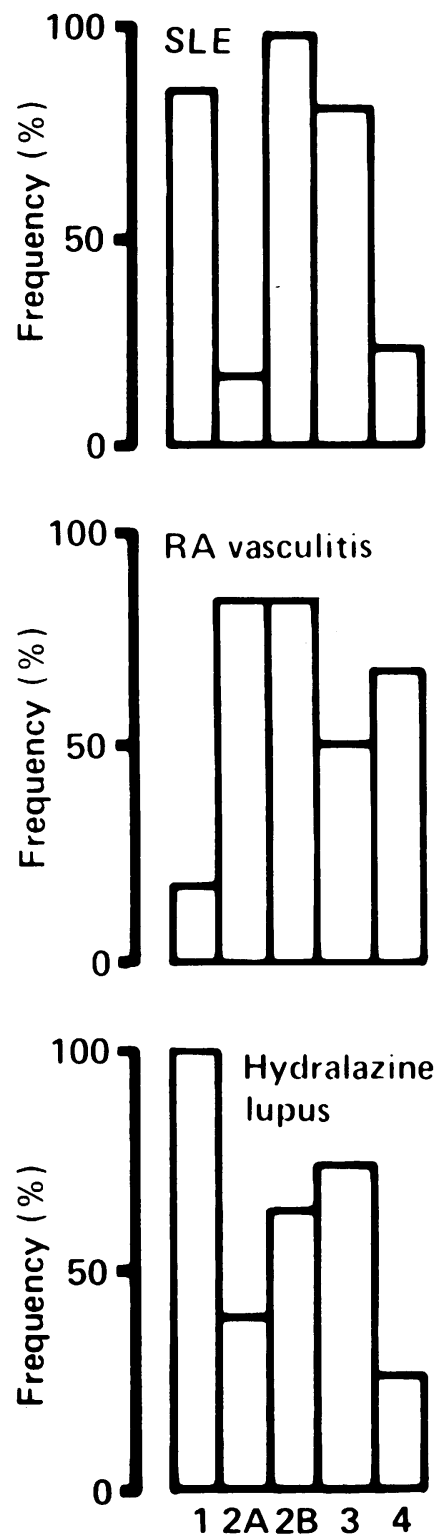

Fig. 7 Disease related patterns of antihistone response. The histograms compare idiopathic SLE, rheumatoid arthritis with vasculitis, and the lupus syndrome induced by hydralazine (data from this study and Ref. 13), showing the frequency with which each histone gave binding values ranked in the top three as opposed to the bottom two results for each serum. When SLE and rheumatoid vasculitis are compared the differences for $H 1, H 2 A$, and $\mathrm{H} 4$ are all significant $(p<0.001,0.001,0.03$ respectively, by $\chi^{2}$ test with Yates's correction). absence of drug induced lupus, or the drug involvech. The heterogeneity of antihistone specificity maj. reflect mixtures of antibodies to individual histons or antigenic cross reactivities between these pros teins. The important point is that individuals diffe $\frac{0}{3}$ but within strict bounds, in their autoimmunes response to a particular agent.

Some differences in autoimmune response may bo drug related. Rubin et al emphasised a switch from IgM to IgG class antihistone antibody at the time procainamide induced lupus appears, ${ }^{26}$ but we could not confirm this with hydralazine. Antihiston antibody was chiefly IgM in one of four hydralazine lupus cases, and our previous studies showed ove? $60 \%$ of hydralazine induced ANA were a mixture of IgG and IgM whether or not the patient had lupus.

A further difference from procainamide is that the ANA induced by hydralazine is usually not detect able on tissues extracted with acid and reconstitute $\overline{\mathbb{Z}}$ with histones. This lack of reactivity with histone reconstituted tissues is now well established ${ }^{6-8}$ (通 Fritzler, personal communication) and indicates a. distinction between the ANA specificities induce $\$$ by hydralazine and procainamide (made apparent because the nucleosome is not reconstituted if native form ${ }^{28}$ ). The amounts of antihistone antibod and total ANA are not always correlated, ${ }^{29}$ and ou present results emphasise that additional antibodyo antigen reactions are involved. A monoclonal anto body to poly(adenosine diphosphate-ribose) gives homogeneous nuclear staining, ${ }^{30}$ and in the presen study there is a close correlation between ANA titre and the Farr assay for antibody to poly(adenosine diphosphate-ribose). Antibody to double stranded DNA may also rise a little,$^{23}$ but cross reactiviti between poly(adenosine diphosphate-ribose) ang DNA is minimal. ${ }^{31}$ Cross reactivity betweeñ. poly(adenosine diphosphate-ribose) and histones has not been excluded by absorption studies but seems unlikely because there was no correlation between the amounts of antibody to these dissimilaps antigens.

Histones, poly(adenosine diphosphate-ribose and DNA are all components of chromatin, and the question arises as to how drugs induce autoimmung ity to these macromolecules. Immunisation of antw mals with hydralazine conjugated to histones of albumin induces antibodies to the $\operatorname{drug}^{32}$ and to single stranded DNA, ${ }^{33}$ but no antihistone ant bodies arise. ${ }^{32}$ Stollar and Ward raised antihistone antibodies by immunisation of rabbits with histoned RNA complexes, ${ }^{34}$ and it may be relevant, there fore, that hydralazine and procainamide can bind to DNA. ${ }^{35}{ }^{36}$ Such altered DNA might overcome T ce tolerance, ${ }^{37}$ permitting an antihapten response to associated macromolecules. It may be relevant both 
that poly(adenosine diphosphate-ribose) is thought to play a part in DNA repair, ${ }^{38}$ and that high titres of antihistone antibodies have been associated with photosensitivity in SLE ${ }^{13}$ Hardin and his colleagues have shown that the antigenic regions on histones, as detected by immunoblotting using histone fragments, are located mainly on the surface of the nucleosome, suggesting that this whole particle is the immunogen. ${ }^{2} 39$ The induction of antilymphocyte antibodies ${ }^{40} 41$ and the expression of DNA $^{42}$ and histones ${ }^{43}$ on lymphocyte surfaces raise the possibility that cell surface material rather than nuclear chromatin is rendered immunogenic by interaction with drugs.

The frequency of ANA induction can be as high as $50-90 \%$ depending on the drug, the dose, and the duration of therapy, yet drug induced lupus supervenes less often. ${ }^{-4}$ Female sex, polymorphic drug metabolism (slow acetylation), and HLA phenotype (DR4) have been implicated as risk factors for the disease, ${ }^{1-4} 44$ and a further important factor may be the ability of complement to clear immune complexes. ${ }^{45}$ Null and non-functioning allotypes of C4 appear to be increased in drug induced lupus, ${ }^{46}$ as also in patients with idiopathic SLE ${ }^{27}$ and their asymptomatic relatives with autoantibodies. ${ }^{48}$ Several lupus inducing drugs block the binding site of activated $\mathrm{C} 4$, with some allotypes perhaps more susceptible than others. ${ }^{49}$ Reidenberg pointed out previously that 'pharmacological' rather than 'immunological' drug concentrations are required for the development of drug induced lupus.$^{50}$ Hence the development of drug induced lupus may depend on a two pronged assault by the drug on chromatin and complement.

We thank Drs S M Chantler, G R V Hughes, D J Ward, and the late Dr D J Lea for their helpful discussions and C C Bunn for the studies of DNA binding and counterimmunoelectrophoresis.

\section{References}

1 Perry H M J. Late toxicity to hydralazine resembling systemic lupus erythematosus or rheumatoid arthritis. Am J Med 1973; 54: $58-72$.

2 Woosley R L. Drayer D E, Reidenberg M M. Nies A S. Carr K. Oates J A. Effects of acetylator phenotype on the rate at which procainamide induces antinuclear antibodies and the lupus syndrome. $N$ Engl J Med 19;8; 298: 1157-60.

3 Mansilla-Tinoco R, Harland S J. Ryan P F J, et al. Hydralazine. antinuclear antibodies and the lupus syndrome. Br Med J 1982 . 284: $936-9$.

4 Cameron H A. Ramsay L E. The lupus syndrome induced by hydralazine: a common complication with low dose treatment. Br Med J 1984; 289: 410-2.

5 Fritzler M J, Tan E M. Antibodies to histones in drug-induced and idiopathic lupus erythematosus. J Clin Invest 1978: 62: $560-7$.

6 Bernstein R M. Harland S J. Tinoco R M. Ryan P F J. Hughes G R V. Portanova J. Hydralazine-induced antinuclear antibody |Abstract|. Arthritis Rheum 1981: 24: s123.
7 Portanova J P. Rubin R L, Joslin F G. Agnello V D. Tan E M. Reactivity of anti-histone antibodies induced by procainamide and hydralazine. Clin Immunol Immunopathol 1982; 25: 67-79.

8 Grossman L. Barland P. Histone reactivity of drug-induced antinuclear antibodies: a comparison of symptomatic and asymptomatic patients. Arthritis Rheum 1981; 24: 927-31.

9 Epstein A. Barland P. The diagnostic value of antihistone antibodies in drug-induced lupus erythematosus. Arthritis Rheum 1985; 28: 158-62.

10 Isenberg I. Histones. Ann Rev Biochem 1979; 48: 159-91.

11 Costa O. Monier J C. Detection of antibodies to histones in human systemic lupus erythematosus and in murine lupus-like syndrome using micro-ELISA. Ann Inst Pasteur Immunol 1983; 134: $365-76$.

12 Hardin J A. Thomas J O. Antibodies to histones in systemic lupus erythematosus: localisation of prominent autoantigens on histones H1 and H2B. Proc Natl Acad Sci USA 1983; 80: 7410-4.

13 Bernstein R M, Hobbs R N. Lea D J. Ward D J. Hughes G R V. Patterns of antihistone antibody specificity in systemic rheumatic disease. I. Systemic lupus erythematosus. mixed connective tissue disease. primary sicca syndrome and rheumatoid arthritis with vasculitis. Arthritis Rheum 1985; 28: 285-93.

14 Hobbs R N, Lea D J, Ward D J. A fluorimetric assay for human antibodies to all the histones. J Immunol Methods 1983; 65: 235-43.

15 Hobbs R N, Lea D J. Phua K K, Johnson P M. Binding of isolated rheumatoid factors to histone proteins and basic polycations. Ann Rheum Dis 1983; 42: 435-8.

16 Griffiths I D, Kane S P. Sulphasalazine-induced lupus syndrome in ulcerative colitis. Br Med J 1977; ii: 1188-9.

17 Walshe J M. Penicillamine and the SLE syndrome. J Rheumatol [Suppl] 1981: 7: 155-60.

18 Wirsen A. Prizidilol, an antihypertensive with precapillary vasodilator and beta-adrenoceptor blocking actions, in primary hypertension. Clin Pharmacol Ther 1981; 29: 588-93.

19 Bernstein R M. Egerton-Vernon J. Webster J. Hydralazineinduced cutaneous vasculitis. $B r$ Med $J$ 1980; 280: 156-7.

20 Hughes G R V. Rynes R I. Gharavi A. Ryan P F J. Sewell J, Mansilla $R$. The heterogeneity of serologic findings and predisposing host factors in drug-induced lupus erythematosus. Arthritis Rheum 1981: 24: 1070-3.

21 Johns $\mathrm{E} \mathrm{W}$. The isolation and purification of histones. In: Stein G. Stein J. Kleinsmith L J, eds. Methods in cell biology. London: Academic Press, 1977: 183-203.

22 Tan E M, Robinson J. Robitaille P. Studies of antibodics to histones by immunofluorescence. Scand J Immunol 1976; 5: $811-8$.

23 Clayton A-L, Bernstein R M. Tavassoli M, et al. Measurement of antibody to poly(adenosine diphosphate-ribose): its diagnostic value in systemic lupus erythematosus. Clin Exp Immunol 1984; 56: 263-71.

24 Pincus T, Schur P H, Rose J A, Decker J L, Talal N. Measurement of DNA-binding activity in systemic lupus erythematosus. N Engl J Med 1969: 281: 701-5.

25 Bernstein R M. Bunn C C. Hughes G R V. Identification of antibodies to acidic antigens by counterimmunoelectrophoresis. Ann Rheum Dis 1982; 41: 554-5.

26 Rubin R L. McNally E M. Nusinow S R. Robinson R A. Tan E M. IgG antibodies to the histone complex H2A-H2B characterize procainamide-induced lupus. Clin Immunol Immunopathol 1985; 36: 49-59.

27 Bernstein R M. Antinuclear antibodies:clinical associations and predisposing factors. University of Cambridge, 1984. (MD thesis.)

28 Laskey R A. Honda B M. Mills A D. Finch J T. Nucleosomes are assembled by an acidic protein which binds histones and transfers them to DNA. Nature 1978: 275: 416-20.

29 Bernstein R M. Hobbs R N. Antibodies to histones: different patterns of response in idiopathic SLE and drug-induced lupus. 
In: Peeters H, ed. Protides of the biological fluids. Oxford: Pergamon, 1985. (Colloqium 33.)

30 Kanai Y, Tanuma S, Sugimura T. Immunofluorescent staining of poly(ADP-ribose) in situ in HeLa cell chromosomes in the $\mathrm{M}$ phase. Proc Natl Acad Sci USA 1981; 78: 2801-4.

31 Okolie E E, Shall S. The significance of antibodies to poly(adenosine diphosphate-ribose) in systemic lupus erythematosus. Clin Exp Immunol 1979: 36: 151-64

32 Buxman M M. The role of enzymatic coupling of drugs to proteins in induction of drug specific antibodies. $J$ Invest Dermatol 1979; 73: 250-5.

33 Yamauchi Y, Litwin A. Adams L. Zimmer H. Hess E V. Induction of antibodies to nuclear antigens in rabbits by immunisation with hydralazine-human serum albumin conjugates. J Clin Invest 1975; 56: 958-69.

34 Stollar B D, Ward M. Rabbit antibodies to histone fractions as specific reagents for preparative and comparative studies. J Biol Chem 1970; 245: 1261-6.

35 Blomgren S E, Vaughan J H. The immunogenicity of photooxidised DNA and of the photo-product of DNA and procainamide-hydrochloride [Abstract]. Arthritis Rheum 1968; 11: 470 .

36 Dubroff L M, Reid R J. Hydralazine-pyrimidine interactions may explain hydralazine-induced lupus erythematosus. Science 1980; 208: 404-6.

37 Weigle W O. Analysis of autoimmunity through experimental models of thyroiditis and allergic encephalomyclitis. Adv Immunol 1980; 30: 159-273.

38 Durkacz B W, Omidijc O, Gray D A, Shall S. (ADP-ribose)n participates in DNA excision-repair. Nature 1980; 283: 593-6.

39 Craft J E, Radding J A, Harding M W. Bernstein R M. Hardin J A. Drug-induced lupus as a model for spontaneous SLE: identification of a common set of autoantigenic histone epitopes. Arthritis Rheum (in press).

40) Bluestein H G. Zvaifler N J, Weisman M H, Shapiro R F
Lymphocyte alteration by procainamide: relation to drug induced lupus erythematosus syndrome. Lancet 1979; ii: 816-9:

41 Ryan P F J. Hughes G R V. Bernstein R M. Tinoco R Dollery $C \mathrm{~T}$. Lymphocytotoxic antibodies in hydralazine? induced lupus erythematosus. Lancet 1979; ii: 1248-9.

42 Campbell S M. Davis J. Bennett R M. T cells secrete DN which binds to B cells and monocytes [Abstract]. Arthri $\overline{\bar{d}}$ Rheum 1982; 25: s107.

43 Rekvig O P. Hannestad K. Human autoantibodies that rea@ with cell nuclei and plasma membranes display specificity fo the octamer of histones $\mathrm{H} 2 \mathrm{~A}, \mathrm{H} 2 \mathrm{~B}, \mathrm{H} 3$ and $\mathrm{H} 4$ in high salf? $J$ Exp Med 1980; 152: 1720-33.

44 Batchelor J R, Welsh K I, Tinoco R M, et al. Hydralazineinduced systemic lupus erythematosus: the influence of HLA DR and sex upon susceptibility. Lancet 1980; i: 1107-9. O

45 Batchelor J R, Fielder A H L, Hing S, et al. Class III MH@ genes and systemic lupus erythematosus. In: Feldmann M, ed Proceedings of the Sixth IR Gene Workshop: Immune Reguld tion. New Jersey: Humana, 1986.

46 Fielder A H L, Walport M J, Batchelor J R, et al. Family study of the major histocompatibility complex in patients wi苗 systemic lupus erythematosus: importance of null alleles of $\mathrm{C} 4 \AA^{\circ}$ and C4B in determining disease susceptibility. Br Med J 1983 286: $425-8$.

47 Walport M J, Elkon K B, Bernstein R M, et al. Autoantibodie and immune complexes in relatives of patients with SLE [Abstract]. Ann Rheum Dis 1983; 42: 217.

48 Sim E, Gill E W, Sim R B. Drugs that induce systemic lupus erythematosus inhibit complement component C4. Lancet $198 \Phi 9$ ii: $422-4$.

49 Schifferli J A, Ng Y C, Peters D K. The role of complement and its receptor in the elimination of immune complexes. $N$ Engly Med 1986; 315: 488-95.

5) Reidenberg M M. Chemical induction of systemic lup erythematosus and lupus-like illnesses. Arthritis Rheum 198कू 24: $10(04-9$ 